Published by Al-Nahrain College of Medicine P-ISSN 1681-6579

E-ISSN 2224-4719

Email: iraqijms@colmed-alnahrain.edu.iq http://www.colmed-alnahrain.edu.iq http://www.iraqijms.net

\title{
The Role of Estrogen and Progesterone on Vaginal Cytology during Proliferative and Secretary Phases of Menstrual Cycle in Women with Polycystic Ovarian Syndrome
}

\author{
Huda R. Kareem ${ }^{1} P h D$, Haider A. Jaafer ${ }^{1} P h D$, Zainab H. Hashim ${ }^{2} P h D$ \\ ${ }^{1}$ Dept. of Human Anatomy, ${ }^{2}$ Dept of Physiology, College of Medicine, Al-Nahrain University, Baghdad, Iraq
}

\section{Abstract \\ Background}

Objective

Methods

Results

Conclusion

Keywords

Citation
In the course of cyclic hormonal fluctuation, cytological changes in the vaginal epithelium can be correlated with the phases of the menstrual cycle, this can be utilized in diagnosis of hormonal status in women with pathological cycles as in polycystic ovarian syndrome (PCOS).

To evaluate the effects of estrogen (E2) and progesterone hormones in PCOS on the vaginal cytology in different phases of menstrual cycle, and its relation to ovulation period.

A non-random sample of one hundred women were enrolled in this study, divided into two groups; 50 women free from PCOS, and 50 were PCOS according to the criteria of Rotterdam 2003. All were underwent hormonal assay including estrogen and progesterone on $2^{\text {nd }}$ and $21^{\text {st }}$ day of the cycle respectively, vaginal smears cytology on the $2^{\text {nd }}$ day, $14^{\text {th }}$ and $21^{\text {st }}$ day of the cycle, stained with $\mathrm{H} \& \mathrm{E}$, the (parabasal, squamous, leukocytes) were identified and counted, ultrasound examination was done on $14^{\text {th }}$ day of the cycle, that divide the sample into ovulatory and an ovulatory subgroups accordingly.

At the $2^{\text {nd }}$ day of the cycle, there was a significant reduction in squamous cell count, highly significant increase in leukocyte, E2 hormone level increased markedly, with a significant negative correlation to leukocytes cells in patients' groups at $P \leq 0.05$. Squamous cells of vaginal smear attained more acidophilic cytoplasm and increase in nuclear pyknosis. At the $14^{\text {th }}$ day of the cycle, a significant increase in squamous cells count at $\mathrm{P} \leq 0.05$, cornified squamous cells predominantly seen associated with low ovulation rates of $44 \%$. Ovulation showed significant reduction in parabasal cells count in patients group at $\mathrm{P} \leq 0.05$. At $21^{\text {st }}$ day of the cycle, progesterone level was reduced with a significant reduction in squamous cells, parabasal cells and leukocytes counts in patients, with no significant correlation between progesterone and vaginal cytology cells, squamous cells consisted of mature cornified cells that seen predominantly in vaginal smear.

Hormonal changes in PCOS presented mainly by the effect of elevated E2 hormone, that associated with increase in squamous cells count and cornification, with reduction in leukocytes and parabasal cells toward mid cycle. Progesterone hormone exert no significant effect on vaginal cytology in PCOS.

PCOS, vaginal cytology, ovulation

Huda R. Kareem, Haider A. Jaafer, Zainab H. Hashim. The role of estrogen and progesterone on vaginal cytology during proliferative and secretary phases of menstrual cycle in women with polycystic ovarian syndrome. Iraqi JMS. 2017; Vol. 15(1): 78-87. doi: 10.22578/IJMS.15.1.10
List of abbreviation: $\mathrm{E2}=$ Estrogen, $\mathrm{H} \& \mathrm{E}=$ Haematoxyline \& Eosin, FSH = Follicular stimulating hormone, $\mathrm{LH}=$ Luteinizing hormone, PCOS $=$ Polycystic ovary syndrome

\section{Introduction}

olycystic ovary syndrome (PCOS) is the
commonest endocrine disturbance
mostly affecting $4-12 \%$ of the women in 
the reproductive age $(1,2)$. This syndrome has the heterogenous collection of the signs and symptoms that gathered together to form a spectrum of disorders with the mild and severe disturbance of reproductive, endocrine and metabolic functions ${ }^{(3)}$.

PCOS is characterized by ovulatory dysfunction, and hyperandrogenism, with complex physiophatology of anovulation (4). However, the Rotterdam European Society of Human Reproduction/American Society for Reproductive Medicine (ESHRE/ASRM)Sponsored PCOS Consensus Workshop Group that convened in 2003 in Rotterdam, required the existence of two of the following three criteria to make the diagnosis of PCOS: oligoovulation or anovulation, clinical or biochemical signs of hyperandrogenism, and polycystic ovaries ${ }^{(5,6)}$.

Because $16-25 \%$ of the normal population has polycystic ovaries appearing on ultrasound (5), the presence of polycystic ovaries was considered to be suggestive but not diagnostic of PCOS. Polycystic ovary appearance at an ultrasound with (ovarian volume $10 \mathrm{ml}$ and/or 12 follicles less than $9 \mathrm{~mm}$ in size) ${ }^{(7)}$.

Accordingly, different patterns of PCOS patients either present as severe phenotype (hyperandrogenism, chronic anovulation, and polycystic ovaries: type I classic PCOS), or patients presenting hyperandrogenism and chronic anovulation but normal ovaries (type II PCOS), the patients with polycystic ovaries had a higher luteinizing hormone/folliclestimulating hormone (LH/FSH) ratio. Ovulation in type II PCOS was relatively common $(28.8 \%$ of patients), and milder clinical and endocrine alterations compared to classic PCOS phenotypes were found. The normal androgenic phenotype was relatively uncommon. These patients had a normal body mass index, insulin sensitivity, and free androgen index, but showed increased levels of $\mathrm{LH}$ and $\mathrm{LH} / \mathrm{FSH}$ ratio ${ }^{(8)}$.

Previously, PCOS was diagnosed on the basis of clinical features of the menstrual dysfunction, obesity, infertility and the direct visualization of the ovaries at the laparotomy ${ }^{(9)}$.

During the reproductive years, PCOS is associated with the important reproductive morbidity, including abnormal bleeding, increased pregnancy loss and complication of pregnancy ${ }^{(10)}$. About $50 \%$ of the women are obese particularly abdominal obesity, imbalance of hormones prevents the ovaries from releasing an egg each month. So, ovulation does not occur and the ovaries produce more immature eggs. These eggs turn into cysts and the ovaries become large and studded with numerous cysts ${ }^{(11)}$.

Nowadays the PCOS are interlinked with many disorders and it is not easy to diagnose the symptoms only with the help of ultrasonography but with some active measures like serum analysis for the detection of the hormonal levels. The easiest way for the detection of the PCOS condition is vaginal smear analysis. The alteration in LH brings out a serious effect in cycle regulation is blocked by the $\mathrm{LH}$ hormone synthesis in excess in the PCOS condition ${ }^{(12,13)}$.

The value of the vaginal smear method for the study of ovarian functions is based upon the response of the vaginal epithelium to the hormones of the ovary. This relationship has been long evident from comparison of the structure of the undeveloped vagina in childhood and the atrophic mucosa of senility with the Histologically normal, fully developed epithelial structure characteristic in sexual maturity; it has more recently also been indicated by the apparent occurrence of rhythmic alterations of the vaginal epithelium during the menstrual cycle (14).

This study aimed to evaluate the effect of ovarian hormones (E2, estrogen) and progesterone in PCOS on:

1. Vaginal epithelium cytology in different days of menstrual cycle including $\left(2^{\text {nd }}\right.$ day, $14^{\text {th }}$ day, $21^{\text {st }}$ day).

2. Correlation of these changes in vaginal epithelial cell counts including (parabasal, squamous, and leukocytes) with ovulation. 


\section{Methods}

A non-random sample of one hundred women were enrolled in this study taken from lum AlBaneen Center for Infertility Therapy and in vitro fertilization (IVF) in Al-Imamein AlKadhimein Medical City, those who were attending the center seeking pregnancy were selected, their phone numbers were taken to follow up them in their subsequent visits within the same menstrual cycle, in the $2^{\text {nd }}, 14^{\text {th }}$, and $21^{\text {st }}$ days to make vaginal smear cytology, with hormonal assay (E2 at $2^{\text {nd }}$ day and progesterone at $21^{\text {st }}$ day), and ultrasound examination at $14^{\text {th }}$ day, they were divided into two groups;

- (Control group): Fifty women free from signs and symptoms of PCOS.

- (Test group): Fifty women with PCOS that fulfill the criteria of Rotterdam $2003^{(6)}$.

For comparative purposes, the cycling profiles of three types of vaginal epithelial cells were assessed throughout the menstrual cycle; these include parabasal cells, squamous cells, and leukocytes.

- Parabasal cells: are small, rounds, slightly oval, with large vesiculated nucleus and small cytoplasm, stained basophilic with H\&E staining.

- Squamous cells: form the largest proportion in vaginal cytology with sharp, flat, angular cytoplasmic borders subdivided into:

- (Precornified) cells: Intermediate stage of their development characterized by basophilic cytoplasm, with intermediate keratohyalin granules, and large vesicular nucleus.

- Superficial squamous cells with acidophilic homogenous cytoplasm and small dark nucleus. (pyknotic).

- Leukocytes: Inflammatory cells that can be normal or abnormal in vaginal cytology appear as dark stained small nuclei with scanty cytoplasm, mainly neutrophil.

\section{Cytological analysis}

The internal vaginal mucosal wall was swabbed with saline-moistened sterile cotton; the swabs were gently rolled onto a clean glass slides. Slide were fixed in 95\% ethyl alcohol for 15 minutes, stained with H\&E stain, as slides pass through descending concentrations of ethyl alcohol; 90\%, 80\%, 70\%, 60\%, dipped in haematoxylin for 2 minutes, then pass under running tab water for 5 minutes, passed to eosin for 1 minute, then pass through ascending concentration of ethyl alcohol 80$100 \%$ (absolute ethyl alcohol), then kept in xylene for 5 minutes, and covered with cover slips (15).

\section{Statistical analysis and level of significance}

Unpaired T-test used to compare between cells count of vaginal cytology (squamous, parabasal, leukocytes) in test and control groups in different days of menstrual cycle, and between ovulatory and an-ovulatory subgroups of control and patient groups in $21^{\text {st }}$ day. Correlation coefficient ( $r$-value) is used to measure the strength of a linear association between two variables (vaginal cytology cells count in relation to hormonal levels E2, progesterone, and ovulation). Fissure exact test used to compare between ovulatory and anovulatory subgroups of patients and control groups. The statistical significance level selected was at $p$-value $\leq 0.05^{(16)}$.

\section{Results}

Distinct cellular changes to the vaginal epithelium were seen at different days of menstrual cycle, these include:

\section{At $2^{\text {nd }}$ day of the cycle}

Significant reduction in the mean number of squamous cells, and highly significant increase in mean number of leukocytes count was found in patients group, while parabasal cells showed no significant changes in patients and control groups (Table 1). With an increase in E2 hormone level in patients group (Table 2), associated with a significant negative correlation to leukocytes cells in patients group (Table 3) at $\mathrm{P} \leq 0.05$. 
Intermediate type of squamous cells predominates in early phase with basophilic cytoplasm that showed keratohyalin granules and vesicular nucleus in control group (Figure
1). In patients group, squamous cells attained more acidophilic cytoplasm and increase in nuclear pyknosis (Figure 2).

Table 1. Mean number of vaginal cells cytology in various days of menstrual cycle in patients and control groups

\begin{tabular}{cccccccc}
\hline $\begin{array}{c}\text { Days of } \\
\text { menstrual } \\
\text { cycle }\end{array}$ & Groups & $\begin{array}{c}\text { Parabasal } \\
\text { cells }\end{array}$ & $\begin{array}{c}\text { P } \\
\text { value }\end{array}$ & $\begin{array}{c}\text { Squamous } \\
\text { cells }\end{array}$ & P value & Leukocytes & P value \\
\hline \multirow{2}{*}{$2^{\text {nd }}$ day } & Patients & $18.52 \pm 5.24$ & 0.08 & $23.52 \pm 5.15$ & $0.002^{*}$ & $5.68 \pm 1.45$ & $<0.001^{*}$ \\
& Control & $16.8 \pm 4.61$ & & $26.4 \pm 3.64$ & & $2.9 \pm 1.11$ & \\
\hline \multirow{2}{*}{$14^{\text {th }}$ day } & Patients & $7.68 \pm 3.32$ & 0.57 & $114.74 \pm 28.2$ & $<0.001^{*}$ & $1.48 \pm 1.35$ & 0.580 \\
& Control & $8.0 \pm 2.32$ & & $79.58 \pm 11.45$ & & $1.32 \pm 1.1$ & \\
\hline \multirow{2}{*}{$21^{\text {st }}$ day } & Patients & $6.42 \pm 3.12$ & $<0.001^{*}$ & $59.82 \pm 10.33$ & $<0.001^{*}$ & $6.42 \pm 3.12$ & $<0.001^{*}$ \\
& Control & $13.72 \pm 4.57$ & & $71.36 \pm 13.9$ & & $13.72 \pm 4.57$ & \\
\hline
\end{tabular}

$*$ Significant $\mathrm{P}$ value $\leq 0.05$

Table 2. Mean values of hormonal assay in patients and control groups

\begin{tabular}{cccc}
\hline & Patients & Control & P value \\
\hline $\begin{array}{c}\text { Estrogen } \\
(\mathrm{ng} / \mathrm{ml})\end{array}$ & $115.8 \pm 32.24$ & $85.9 \pm 25.5$ & $<0.001^{*}$ \\
$\begin{array}{c}\text { Progesterone } \\
(\mathrm{pg} / \mathrm{ml})\end{array}$ & $3.68 \pm 2.37$ & $9.48 \pm 3.98$ & $<0.001^{*}$ \\
\hline
\end{tabular}

$*$ Significant $P$ value $\leq 0.05$

Table 3. Correlation between vaginal cells and E2 level in $2^{\text {nd }}$ day of the cycle

\begin{tabular}{|c|c|c|c|c|}
\hline \multicolumn{2}{|c|}{ Groups } & \multirow{2}{*}{$\begin{array}{c}\text { Squamous cells } \\
-0.201\end{array}$} & \multirow{2}{*}{$\begin{array}{c}\text { Parabasal cells } \\
-0.04\end{array}$} & \multirow{2}{*}{$\begin{array}{c}\text { leukocytes } \\
-0.331\end{array}$} \\
\hline & r value & & & \\
\hline Patients & $P$ value & 0.162 & 0.782 & $0.019 *$ \\
\hline \multirow{2}{*}{ Control } & r value & 0.11 & 0.096 & 0.105 \\
\hline & $P$ value & 0.44 & 0.509 & 0.466 \\
\hline
\end{tabular}

*Significance of $r$ value at $P \leq 0.05$

\section{At $14^{\text {th }}$ day of the cycle}

A significant increase in the mean number of squamous cells count seen in patients group at $\mathrm{P}$-value $\leq 0.05$. Parabasal and leukocytes cells showed no significant changes in patients and control groups (Table 1).
Ovulation rate was higher in control group than in patients group with $44 \%$ in patients group and $82 \%$ in control group (Table 4), with a significant reduction in parabasal cells count in ovulatory sub-group at $\mathrm{P} \leq 0.05$. 
In control group, leukocytes count showed a significant increase in ovulatory sub- groups at $\mathrm{P} \leq 0.05$ (table 5).

Squamous cells are the dominant cell in cytological examination being of intermediate type in control group, with basophilic cytoplasm and vesicular nucleus, changed to cornified squamous cells in patients (Figures $3,4)$.

Table 4. Ovulation documentation by ultrasound on $14^{\text {th }}$ day of the cycle in patients and control groups

\begin{tabular}{cccc}
\hline Groups & Positive & Ovulation & P value \\
& No. (\%) & $\begin{array}{c}\text { Negative } \\
\text { No. (\%) }\end{array}$ & \\
\hline Patients & $22(44)$ & $28(56)$ & $<0.001^{*}$ \\
Control & $41(82)$ & $9(18)$ & \\
\hline
\end{tabular}

* Significant $\mathrm{P}$ value $\leq 0.05$

Table 5. Vaginal cytology cells mean values in relation to ovulation in patients and control groups at $14^{\text {th }}$ day of the cycle

\begin{tabular}{|c|c|c|c|c|}
\hline Groups & Sub-groups & Squamous cells & Parabasal cells & leukocytes \\
\hline \multirow{2}{*}{$\begin{array}{l}\text { Patients } \\
\text { group }\end{array}$} & Ovulatory & $110.41 \pm 26.56$ & $6.64 \pm 2.75$ & $1.5 \pm 1.37$ \\
\hline & anovulatory & $118.14 \pm 29.4$ & $8.5 \pm 3.55$ & $1.46 \pm 1.37$ \\
\hline \multicolumn{2}{|c|}{$P$ value } & 0.335 & $0.042^{*}$ & 0.92 \\
\hline \multirow{2}{*}{ Control group } & Ovulatory & $80.2 \pm 12.05$ & $7.88 \pm 2.29$ & $1.46 \pm 1.61$ \\
\hline & anovulatory & $76.78 \pm 8.12$ & $8.56 \pm 2.51$ & $0.67 \pm 0.28$ \\
\hline \multicolumn{2}{|c|}{$P$ value } & 0.135 & 0.471 & $0.049 *$ \\
\hline
\end{tabular}

* Significant $P$ value $\leq 0.05$.

\section{At $21^{\text {st }}$ day of the cycle}

A significant reduction in the mean number of parabasal cells, squamous cells and leukocytes were found in patients group at $\mathrm{P} \leq 0.05$ (Table 1).

Progesterone level is reduced in patients group that measured at $21^{\text {st }}$ day of the cycle (Table 2). Its effect on vaginal epithelium is seen as mature cornified squamous cells rather than of intermediate squamous epithelial cells in control group (Figures 5,6).
No significant correlation was found between progesterone and vaginal epithelial cells in control and patients' groups at $P \leq 0.05$ (Table $6)$.

\section{Discussion}

Vaginal cytology is an easy and cheap method, with great value in determines the phase of the menstrual cycle in human with normal menstrual cycles. In this study, we need to find if vaginal cytology is applicable in defining the phase of menstrual cycle in PCOS.

Table 6. Correlation between vaginal cells and progesterone level at $21^{\text {st }}$ day of the cycle

\begin{tabular}{ccccc}
\hline Groups & & Squamous cells & Parabasal cells & Leukocytes \\
\hline \multirow{2}{*}{ Patients } & r value & -0.218 & -0.245 & 0.151 \\
& P value & 0.129 & 0.086 & 0.295 \\
\hline \multirow{2}{*}{ Control } & r value & 0.005 & 0.094 & -0.116 \\
& P value & 0.97 & 0.517 & 0.422 \\
\hline
\end{tabular}

* Significant $P$ value $\leq 0.05$. 


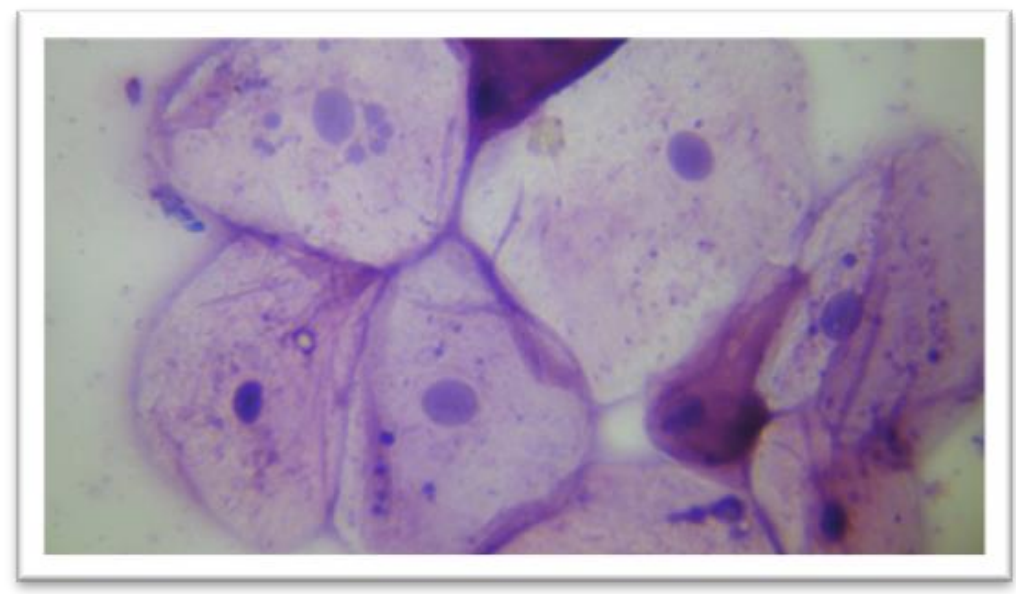

Figure 1. Cells of vaginal cytology in $2^{\text {nd }}$ day of menstrual cycle (control group) showed (precornified) squamous cells, with vesicular nucleus, basophilic cytoplasm and keratohyalin granules. H\&E, 40X

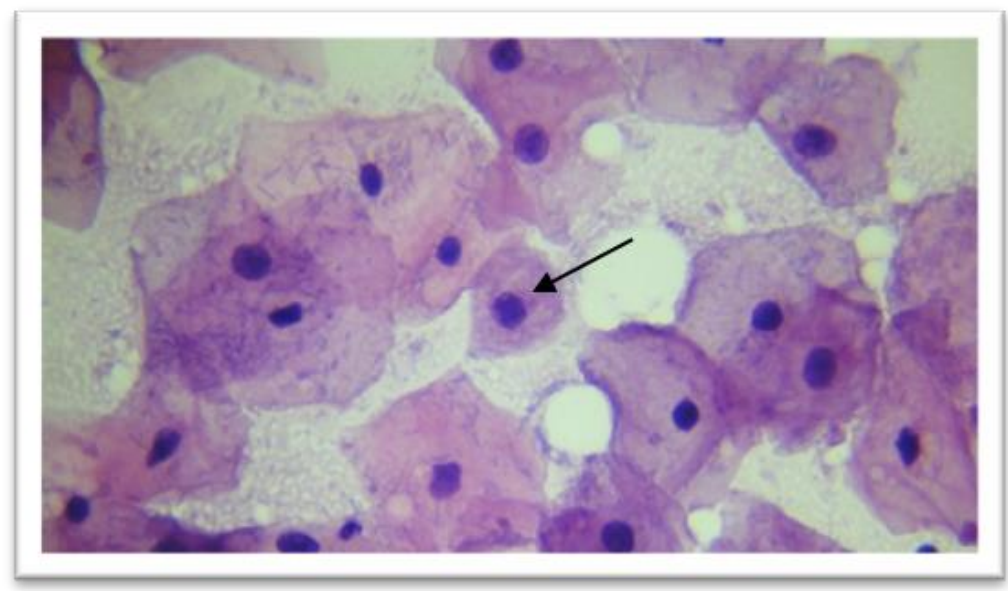

Figure 2. Cells of vaginal cytology at $2^{\text {nd }}$ day of menstrual cycle in (patients group) showed increase in squamous cells acidophila, and pyknosis of their nuclei, keratohyali granules still present, parabasal cell seen (arrow). H\&E, 40X

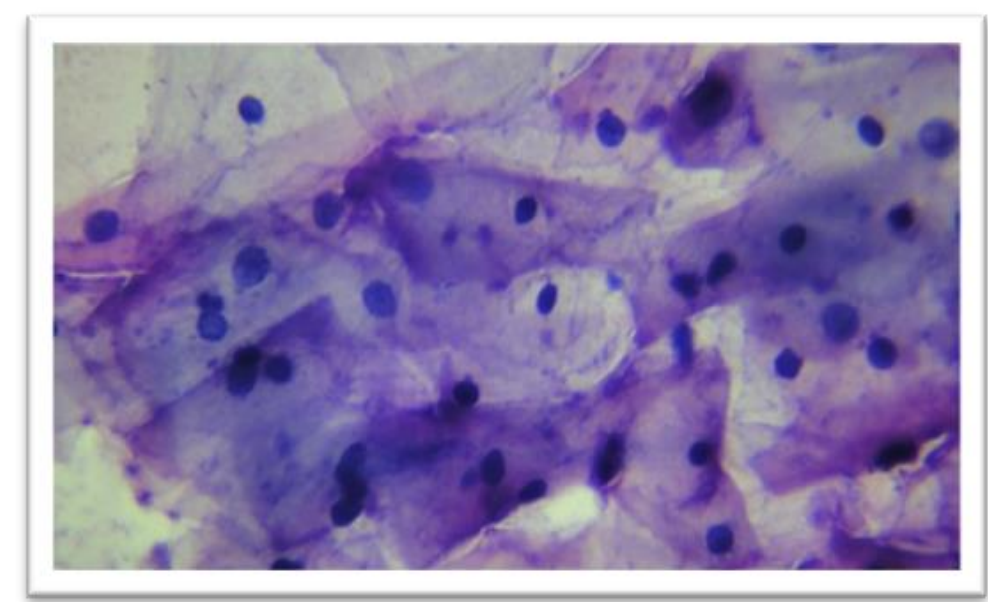

Figure 3. Vaginal cytology in control group at $14^{\text {th }}$ day of the cycle showed predominant squamous cells of pre-cornified type. H\&E, $40 X$ 
Kareem et al, The Role of Estrogen and Progesterone on Vaginal Cytology ....

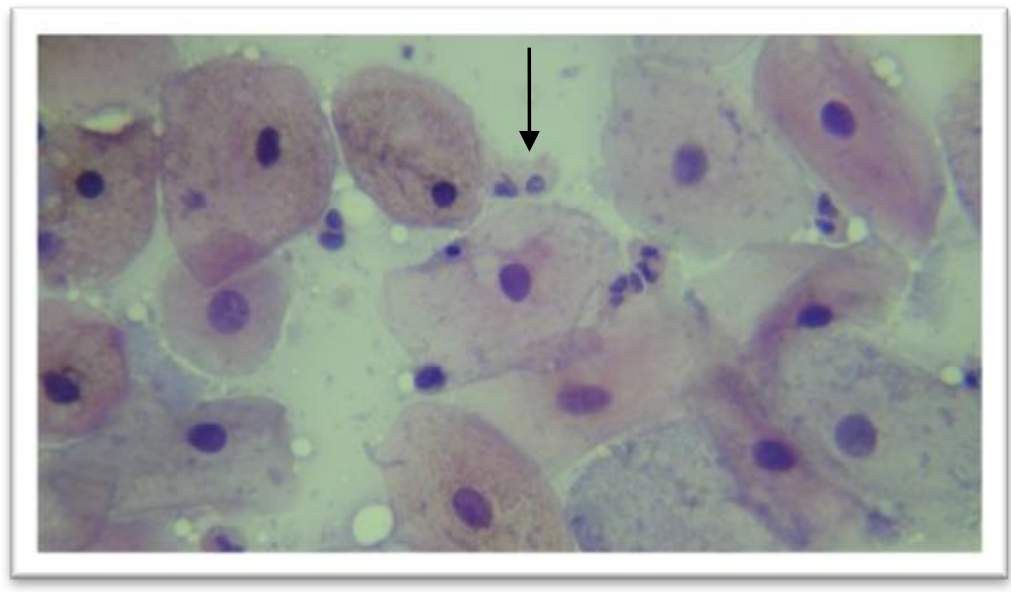

Figure 4. Vaginal cytology in patients group at $14^{\text {th }}$ day of the cycle showed squamous cells of both pre-cornified and cornified types, and leukocytes (arrow). H\&E, 40X

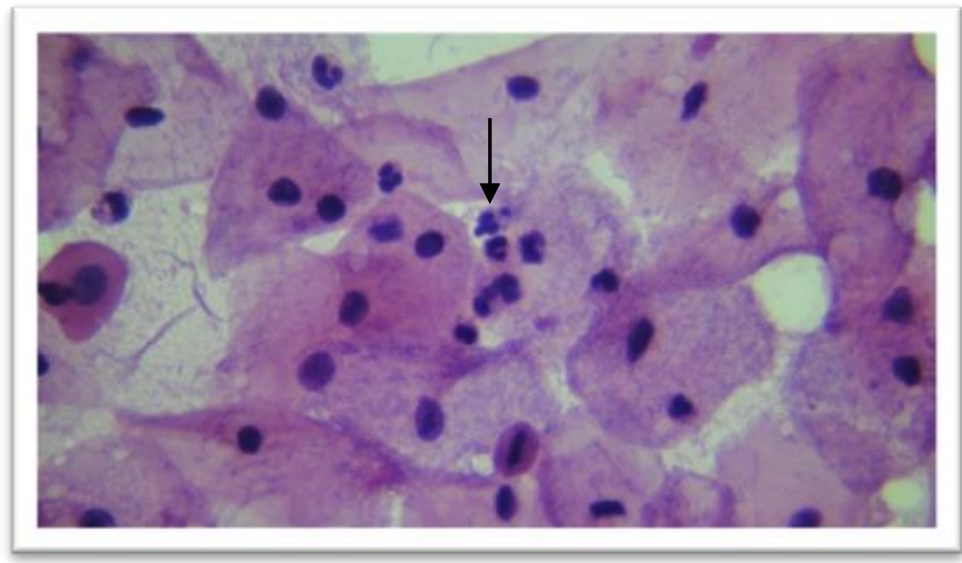

Figure 5. Vaginal cytology in control group at $21^{\text {st }}$ day of the menstrual cycle showed mature squamous cells of cornified types, and leukocytes (arrow). H\&E, 40X

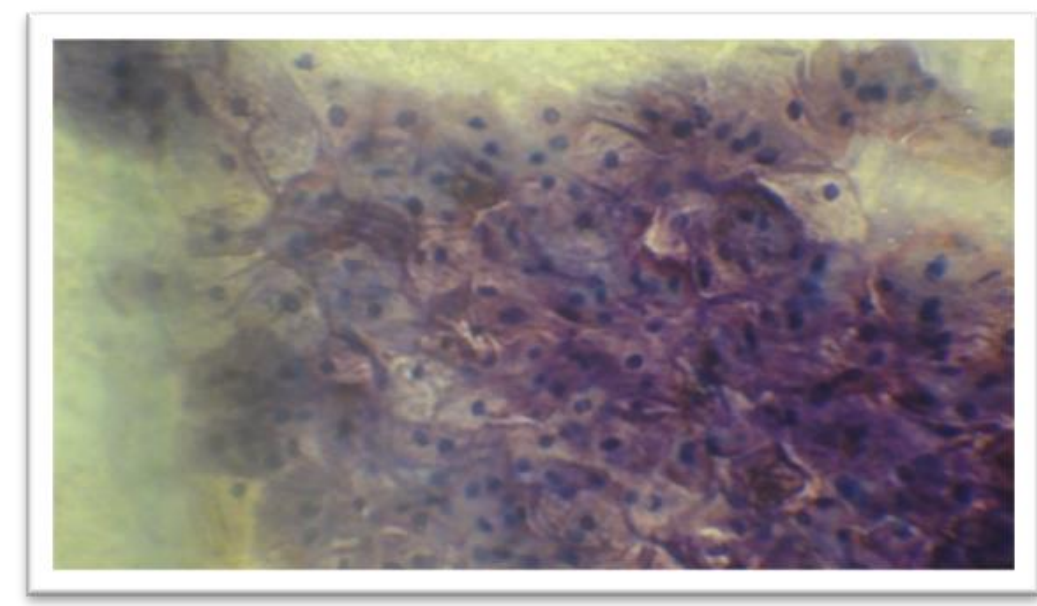

Figure .6. Vaginal cytology in patients group at $21^{\text {st }}$ day of the cycle showed cornified squamous cells. H\&E, $40 X$ 
In patients group, at $2^{\text {nd }}$ and $14^{\text {th }}$ day of the cycle, the increase in mean number and cornification of vaginal squamous cells could be related to elevation in serum E2 level. Thus, estrogens that secreted by maturing follicles can cause thickening of vaginal lining, epithelium moving the cells away from their blood supply, this agreed with (Weiss et al 2004) who mentioned that vaginal cytology provides a useful qualitative measure of cyclic hormonal events that correlates well with endometrial biopsies and urinary estrogen profiles ${ }^{(17)}$.

The significant reduction in leukocytes count in patients group, could be due to hormonal imbalance specifically high E2 level that could act as an immunomodulator. Estrogens act on leukocytes and influence their number and function, through binding to specific estrogen receptors on the leukocytes ${ }^{(18)}$.

The significant negative correlation between E2 level and leukocytes count at $2^{\text {nd }}$ day of the cycle in patients group also related to high E2 level as it acts on the immune system and inflammation, studies have shown that there is clear sex bias in disease presentation, and estrogens have been suggested to be responsible for these differences, these diseases are often associated with defect in leukocyte infiltration and immune dysfunction. Xiang et al. in $2004{ }^{(19)}$ mentioned that E2 inhibits the migration of inflammatory cells, particularly granulocytes, into sites of tissue (20).

The significant increase in parabasal cells count in anovulatory subgroups of patients group could be due to that estrogen effect on parabasal cells (near blood supply), changed into the cornified cells (away from blood supply), their nucleus become smaller, pyknotic. This has been mentioned in the presence of estrogen, epithelial cells mature, creating notable condensation (pyknosis) of the nucleus ${ }^{(21)}$.

The hormonal imbalance that prevents the ovaries from releasing an egg each month, the estrogen hormone continues to increase from the developing follicles that later turned into cysts, this estrogen hormone intern lead to increase in mature superficial nucleated squamous epithelial cells, with predominately pyknotic nuclei ${ }^{(22)}$.

The significant reduction of leukocytes count in an ovulatory subgroups of control group, could be due to failure of ovulation. This explained as continuous rise in E2 level unopposed by $\mathrm{LH}$ regulation, that may lead to continuation action of E2 on vaginal epithelium, as an immunemodulator affect the expression of a number of gene pathways associated with innate immunity, epithelial differentiation, wound healing, and antiviral responses (23).

At $21^{\text {st }}$ day of the cycle squamous cells, leukocytes and parabasl cells reduced in patient group, without any significant correlation to progesterone level that showed reduction in patients group, this could be due to failure of ovulation in patients group as $44 \%$ of them showed documentation of ovulation in ultrasound at $14^{\text {th }}$ day of the cycle.

The presence of precornified and cornified epithelial cells in secretory phase in control group could due to atrophic changes in ovarian follicles that changed to corpus albicans, and lead to reduction in E2 level and this lead to reduction in cornification or keratinization of vaginal epithelium.

Studies correlating variations in vaginal cytology with serum gonadotropins and progesterone and urinary estrogens showed that the karyo-pyknotic index of vaginal cells, which is (average of superficial to basal cells) increases gradually to mid-cycle and peaks on the day after the LH surge. Thereafter, there is a steady decline of the index to the end of the menstrual cycle, when it reaches levels below those in the early proliferative phase. The mean peak of the index is reached 2 days after the total estrogen peak. This lag period is probably required before the vaginal epithelium responds to increased estrogenic stimulation (24).

This study concluded that hormonal changes in PCOS presented mainly by the effect of E2 hormone, that associated with increase in squamous cells count and cornification, with reduction in leukocytes and parabasal cells toward mid cycle. Progesterone hormone exert no significant effect on vaginal cytology in PCOS. 


\section{Acknowledgments}

Authors sincerely thanks all staff of lum AlBaneen Centre for Infertility Therapy and IVF in Al-Imamein Al-Kadhimein Medical City. Also, authors appreciate and thanks Dr. Majid $\mathrm{H}$. Ahmed for his support in statistical analysis.

\section{Author contribution}

Dr. Hashim: Collection of samples, and follow up the patients in subsequent visits for the ultrasound and hormonal essay.at $2^{\text {nd }}, 14^{\text {th }}, 21^{\text {st }}$ day of the cycle. Dr. Kareem: Writing the paper and handling $\mathrm{H} \& \mathrm{E}$ staining of vaginal cytological samples and examination. Dr. Jaafar: Photographing of slides.

\section{Conflict of interest}

Authors declare there is no conflict of interest.

\section{Funding}

Self-funding.

\section{References}

1. Knochenhauer ES, Key TJ, Miller KM, et al. Prevalence of the polycystic ovary syndrome in unselected black and white women of the southeastern United States: a prospective study. J Clin Endocrinol Metab. 1998; 83: 3078-82. doi: 10.1210/jcem.83.9.5090.

2. Farah LH, Lazenby AJ, Boots LR, et al. Prevalence of polycystic ovary syndrome in women seeking treatment from community electrologists. Alabama professional electrology association study group. J Reprod Med. 1999; 44: 870-4.

3. Balen $A H$, Conway GS, Kaltsas G. Polycystic ovary syndrome: the spectrum of the disorder in 1741 patients. Hum Reprod. 1995; 10: 2107-11.

4. Carmina E. PCOS metabolic impact and long-term management. Minerva Ginecol. 2012; 64(6): 501-5.

5. Polson DW, Wadsworth J, Adams J, et al. Polycystic ovaries: A common finding in normal women. Lancet. 1988; 1: 870-2.

6. Rotterdam ESHRE/ASRM-Sponsored PCOS Consensus Workshop Group: Revised 2003 consensus on diagnostic criteria and long-term health risks related to polycystic ovary syndrome. Fertil Steril. 2004; 81: 19-25.

7. Azziz R, Carmina E, Dewailly D, et al. Task force on the phenotype of the polycystic ovary syndrome of the androgen excess and PCOSS Society. The Androgen Excess and PCOS Society criteria for the polycystic ovary syndrome: the complete task force report. Fertil Steril. 2009; 91: 456-88. doi: 10.1016/j.fertnstert.2008.06.035.

8. Guastella E, Longo RA, Carmina E. Clinical and endocrine characteristics of the main polycystic ovary syndrome phenotypes. Fertil Steril. 2010; 94(6): 197201. doi: 10.1016/j.fertnstert.2010.02.014.

9. Zawadzki JK, Dunaif A. Diagnostic criteria for polycystic ovary syndrome: towards a rational approach. In: Dunaif A, Givens JR, Haseltine FP (eds). Polycystic ovary syndrome. Oxford, UK: Blackwell; 1992. p. 59-69.

10. Carmina E. Diagnosing PCOS in women who menstruate regularly. Contemporary OB/GYN. 2003; 1: 53-64.

11. King J. Polycystic ovary syndrome. J Midwifery Women's Health. 2006; 51(6): 415-20. 10.1016/j.jmwh.2006.01.008.

12. Zangeneh FZ, Naghizadeh M, Minaee B, et al. PCOS and Sympathetic outcome: Role of the central and peripheral nervous system in ovarian function of rat. Asian J Pharmaceut Clin Res. 2012; 5(2): 26-32.

13. Chang RA. A practical approach to the diagnosis of the polycystic ovary syndrome. Am J Obstet Gynecol. 2004; 191: 713-7. doi: 10.1016/j.ajog.2004.04.045.

14. Mack HC. Vaginal smear technic: its use in the diagnosis of ovarian failure, as an index to efficacy of endocrine therapy and as a human assay method. J Clin Endocrinol Metab. 1943; 3(3): 169-78. doi: https://doi.org/10.1210/jcem-3-3-169.

15. Nayar R, Wilbur D (eds). The Bethesda system for reporting cervical cytology; definitions, criteria, and explanatory notes. 2nd ed. New York: Springer; 2003.

16. StatSoft, Inc. Electronic Statistics Textbook. Tulsa, OK: StatSoft. Web: http://www.statsoft.com/textbook/, 2013. Accessed at Jul $18^{\text {th }} 2016$.

17. Weiss R V, Clapauch R. Female infertility of endocrine origin. Arq Bras Endocrinol Metab. 2014; 58(2): 14452. http://dx.doi.org/10.1590/0004-2730000003021.

18. Bouman A, Heineman MJ, Faas MM. Sex hormones and the immune response in humans. Hum Reprod Update. 2005; 11(4): 411-23. doi: 10.1093/humupd/dmi008.

19. Cutolo M, Brizzolara R, Atzeni F, et al. (2010) The immunomodulatory effects of estrogens: clinical relevance in immune-mediated rheumatic diseases. Ann N Y Acad Sci. 2010; 1193: 36-42. doi: 10.1111/j.1749-6632.2009.05383.x.

20. Dongqi Xing, Andrew Miller, Lea Novak, et al. Estradiol and progestins differentially modulate leukocyte infiltration after vascular injury. Circulation. 2004; 109(2): 234-41. doi: 10.1161/01.CIR.0000105700.95607.49.

21. Pandit AA, Kalgutkar AK. The value of vaginal cytology in prediction of labour with special reference to eosinophilic and karyopyknotic indices. J Postgrad Med. 1986; 32(4): 210-3.

22. Zondek B, Toaff R, Rozin S. Cyclic changes in the vaginal but not in the uterine mucosa of amenorrheic women induced by a single injection of estrone and progesterone precipitates. Clin Endocrinol. 1950; 10: 615-22. doi: 10.1210/jcem-10-6-615.

23. Ayehunie $S$, Islam $A$, Cannon $C$, et al. Characterization of a hormone-responsive organotypic human vaginal tissue model: morphologic and immunologic effects. 
Iraqi JMS 2017; Vol. 15(1)

Reprod Sci. 2015; 22: 980-90. doi: $10.1177 / 1933719115570906$.

24. Moghissi, K, Puscheck, E, et al. Glob. libr. women's med. 2015. doi: 10.3843/GLOWM.10325. (ISSN: 1756-2228)
Correspondence to Dr. Zainab H. Hashim E-mail: zainab_hashim69@colmedalnahrain.edu.iq

Received 11 ${ }^{\text {th }}$ Aug. 2016

Accepted 4 ${ }^{\text {th }}$ Dec. 2016 